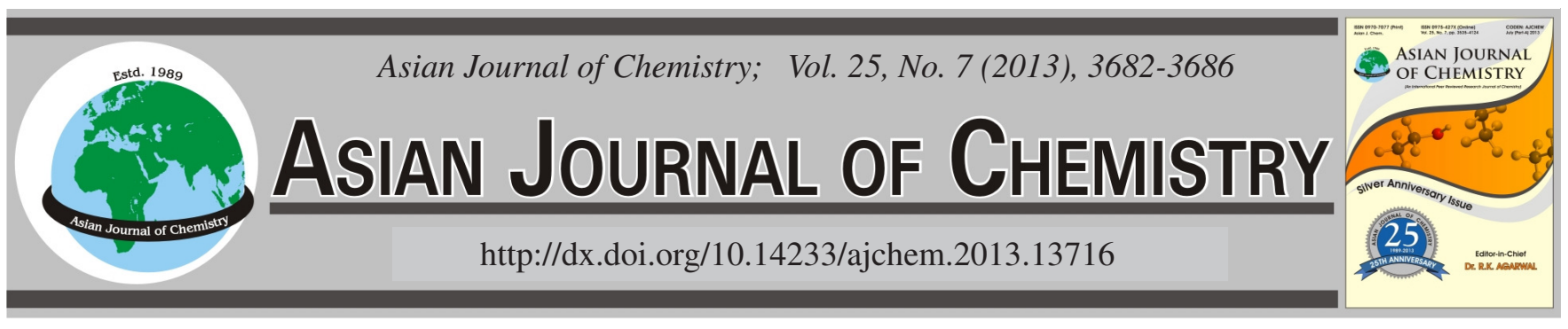

\title{
Spectrophotometric Determination of Nor-Epinephrine Serotonin Reuptake Inhibitor (SNRI) Drug Milnacipran in Pure and in Dosage Forms
}

Gautam Singhvi*, Priyanka Kalantare, Dhoot Harish and Ranendra N. Saha

Department of Pharmacy, Faculty Division III, Birla Institute of Technology and Science, Vidya Vihar, Pilani-333 031, India

*Corresponding author: E-mail: singhvigautam@gmail.com

(Received: 12 March 2012;

Accepted: 9 January 2013)

AJC-12674

\begin{abstract}
Milnacipran hydrochloride is an antidepressant drug belonging to the class of serotonin and nor-adrenaline reuptake inhibitors. Rapid and cost effective UV-spectrophotometric methods were developed for the estimation of milnacipran hydrochloride in bulk, pharmaceutical formulations and in vitro release samples. Milnacipran hydrochloride was estimated at $220 \mathrm{~nm}$ wavelength in the phosphate buffer $(\mathrm{pH}=$ 6.8 buffer) and hydrochloric acid buffer $\left(\mathrm{pH}=1.2\right.$ buffer). Linearity range was found to be $5-30 \mu \mathrm{g} \mathrm{mL} \mathrm{m}^{-1}$ in both medium. The regression equations were found to be: absorbance $=0.0405 \times$ concentration in $\mu \mathrm{g} \mathrm{mL}^{-1}+0.0198(\mathrm{r} 2=0.998)$ in the $\mathrm{pH} 6.8$ buffer and absorbance $=0.03904 \times$ concentraion in $\mu \mathrm{g} \mathrm{mL}^{-1}+0.0598(\mathrm{r} 2=0.999)$ in $\mathrm{pH} 1.2$ buffer. The apparent molar absorptivity was found to be $1.148 \times 10^{4}$ $\mathrm{mol}^{-1} \mathrm{~cm}^{-1}$ in $\mathrm{pH} 6.8$ buffer and $1.105 \times 10^{4} \mathrm{~mol}^{-1} \mathrm{~cm}^{-1}$ in $\mathrm{pH} 1.2$ buffer. In both the proposed methods Sandell's sensitivity was found to be about $0.025 \mu \mathrm{g} \mathrm{cm}^{-2} / 0.001 \mathrm{~A}$. These methods were tested and validated for various parameters according to ICH guidelines and USP. The quantitation limits were found to be 1.6046 and $0.9653 \mu \mathrm{g} \mathrm{mL}^{-1}$ in $\mathrm{pH} 6.8$ buffer and $\mathrm{pH} 1.2$ buffer, respectively. The results demonstrated that the procedure is accurate, precise and reproducible (relative standard deviation $<2 \%$ ), while being simple, cheap and less time consuming and can be suitably applied for the estimation of milnacipran hydrochloride in routine analysis.
\end{abstract}

Key Words: Milnacipran, UV-spectrophotometric methods, Validation.

\section{INTRODUCTION}

Milnacipran hydrochloride ((Z)-1-diethylaminocarbonyl2-aminoethyl-1-phenyl-cyclopropane hydrochloride) is a cyclopropane derivative with antidepressant properties (Fig. 1). It is a nor-epinephrine serotonin reuptake inhibitor (NSRI) which is a new class of antidepressants ${ }^{1,2}$. It has almost equal potency for inhibiting the reuptake of both noradrenaline and serotonin in the ratio of almost 3:1 respectively, with fewer side effects as compared to the TCA's and more efficacious than SSRI's. In January 2009, milnacipran hydrochloride was approved by US FDA for the management of fibromyalgia ${ }^{3,4}$.

Recently, milnacipran hydrochloride is also approved for the treatment of chronic pain conditions like fibromyalgia and lupus for which no effective treatment is available till date. Due to all these clinical advantages of milnacipran hydrochloride over the other antidipressants and its other possible off label indications like anxiety disorders, panic disorders, neuropathic pain, obsessive compulsive disorder and stress incontinence there is increase in number of milnacipran hydrochloride formulations in the market ${ }^{4}$. Extensive literature survey has revealed that isocratic RP-HPLC method for the bulk and capsule formulation, Chiral RP-HPLC method for determination of milnacipran hydrochloride in tablet formu- lation and RP-HPLC method for determination of milnacipran hydrochloride in Human plasma have been developed. But all these chromatographic techniques are not suitable for the routine analysis of milnacipran hydrochloride; hence there is a need for the development of simple, validated and cost effective UV-spectrophotometric method ${ }^{5-10}$.

The basic aim of this study was to develop and validate simple and cost effective analytical method for estimation of milnacipran hydrochloride in Bulk and Pharmaceutical formulations and in vitro dissolution studies of the oral formulations.<smiles>CCN(CC)C(=O)C1(c2ccccc2)CC1CN</smiles>

Fig. 1. Structure of milnacipran hydrochloride 
TABLE-1

CALIBRATION DATA OF THE DEVELOPED METHODS (EACH VALUE IS RESULT OF NINE SEPARATE DETERMINATIONS)

\begin{tabular}{ccc|ccc}
\hline \multicolumn{2}{c|}{ Phosphate buffer medium } & \multicolumn{3}{c}{ Hydrochloric acid medium } \\
\hline $\begin{array}{c}\text { Drug concentration } \\
\left.(\mu \mathrm{g} \mathrm{mL})^{-1}\right)\end{array}$ & $\begin{array}{c}\text { Absorbance at } 220 \\
\mathrm{~nm}\left( \pm \text { S.D. }{ }^{\mathrm{a}}\right)\end{array}$ & R.S.D $^{\mathrm{b}}(\%)$ & $\begin{array}{c}\text { Drug concentration } \\
\left.(\mu \mathrm{g} \mathrm{mL})^{-1}\right)\end{array}$ & $\begin{array}{c}\text { Absorbance at } 220 \mathrm{~nm} \\
\left( \pm \text { S.D. }{ }^{\mathrm{a}}\right)\end{array}$ & R.S.D $^{\mathrm{b}}(\%)$ \\
\hline 5 & $0.2130 \pm 0.003$ & 1.40 & 5 & $0.2454 \pm 0.002$ & 0.99 \\
10 & $0.4109 \pm 0.006$ & 1.65 & 10 & $0.4500 \pm 0.004$ & 0.87 \\
15 & $0.6459 \pm 0.006$ & 1.07 & 15 & $0.6582 \pm 0.004$ & 0.54 \\
20 & $0.8494 \pm 0.006$ & 0.73 & 20 & $0.8397 \pm 0.003$ & 0.40 \\
25 & $1.0509 \pm 0.007$ & 0.71 & 25 & $1.0464 \pm 0.005$ & 0.49 \\
30 & $1.2082 \pm 0.005$ & 0.42 & 30 & $1.2172 \pm 0.002$ & 0.20 \\
\hline
\end{tabular}

${ }^{\mathrm{a}}$ Standard deviation. ${ }^{\mathrm{b}}$ Relative standard deviation

\section{EXPERIMENTAL}

Milnacipran hydrochloride (API) was obtained as gift samples from Torrent Pharmaceutical Ltd. Ahmedabad, India. Formulations containing milnacipran hydrochloride: Milnace and Milborn labeled to contain $50 \mathrm{mg}$ of milnacipran hydrochloride per capsule were purchased from local Indian market. All other chemicals and reagents used were of analytical grade.

A double-beam Jasco (Japan) UV-VIS-NIR spectrophotometer, modelV570 connected to computer loaded with spectra manager software. For intermediate precision study a double-beam Perkin Elmer UV-VIS spectrophotometer, model LAMBDA EZ210 connected to computer loaded with PESSW software (Version 1.2 and Revision E). Both the instruments have an automatic wavelength accuracy of $0.1 \mathrm{~nm}$ and matched quartz cells of $10 \mathrm{~mm}$ path length.

Analytical method: Various media were screened to develop a suitable UV-spectrophotometric method for the analysis of milnacipran hydrochloride in formulations. Criteria for the selection of media were sensitivity, ease of sample preparation, economy of method and its applicability. Drug solutions in the selected media were scanned in the range from 200-400 nm wavelengths for selecting the wavelength of analysis. Absorbance at the selected wavelength was determined and apparent molar absorbtivity and Sandal's sensitivity were calculated.

Calibration standards: Two different stock solutions of $100 \mu \mathrm{g} / \mathrm{mL}$ were prepared in the phosphate buffer $(\mathrm{pH}=6.8)$ and hydrochloric acid buffer $(\mathrm{pH}=1.2)$ by dissolving $10 \mathrm{mg}$ of the drug in $100 \mathrm{~mL}$ of the respective buffer media. Different concentrations were prepared from stock solution by transferring aliquots of stock solutions into a series of $10 \mathrm{~mL}$ standard volumetric flasks and volumes were made with respective media. Six different concentrations were prepared in the range of $5-30 \mathrm{ug} / \mathrm{mL}$ of milnacipran hydrochloride in the respective medium for calibration curve development. Milnacipran hydrochloride was estimated at $220 \mathrm{~nm}$ wavelength in both medium. The calibration data are presented in the Table-1.

Validation of analytical method: The developed method was validated in terms of specificity, selectivity, limit of detection, limit of quantification, linearity and range, precision, accuracy and robustness as per USP and ICH guidelines ${ }^{11-13}$.

Specificity and selectivity: Specificity and selectivity of the proposed method was established by preparing drug solution $(10 \mu \mathrm{g} / \mathrm{mL})$ in both media along with and without common excipients (lactose, micro crystalline cellulose, starch, polyvinyl pyrrolidone K-30, talc, magnesium stearate etc.). All samples were scanned from 200-400 nm at speed of 200 $\mathrm{nm} / \mathrm{min}$ to observe any change in the absorbance at respective wavelength and spectrum.

Accuracy: Accuracy of proposed method was determined by preparing different levels of drug concentrations (LQC, MQC, HQC) in both media from the independent stock solution and analyzed $(\mathrm{N}=9)$. Mean percentage recovery and percentage relative error was used for assessing the accuracy (Table-3). Accuracy of the developed method was further supported by performing standard addition method. In this method different concentration of pure drug $(5,12,20 \mathrm{ug} / \mathrm{mL}$ in the phosphate buffer and hydrochloric acid buffer) were added to known pre analyzed formulation sample and total concentration was determined using the proposed methods $(\mathrm{N}$ $=3$ ). The amount of added concentration was determined by calculating percent recovery $\%$ recovery $=\left[\left(\mathrm{C}_{\mathrm{v}}-\mathrm{C}_{\mathrm{u}}\right) / \mathrm{C}_{\mathrm{a}}\right] \times 100$, where $\mathrm{C}_{\mathrm{v}}$ is total drug concentration measured after standard addition. $\mathrm{C}_{\mathrm{u}}$ is drug concentration in formulation, $\mathrm{C}_{\mathrm{a}}$ is drug concentration added to formulation (Table-4).

Precision: Repeatability was determined by using different level of drug concentration (same concentration as in accuracy study) prepared from the independent stock solution and analyzed $(\mathrm{N}=9)$. Intraday precision was determined by analyzing three different concentration of drug in triplicate for three times in same day $(\mathrm{N}=27)$. Interday precision was performed by following same procedure at three different days. Instrument variation was determined by reanalyzing three different concentration (LQC, MQC and HQC) samples using Perkin-Elmer instrument by same method. The relative standard deviation (in \%) of the predicted concentrations from the regression equation was taken as precision (Table-5).

Linearity: Linearity of the proposed method was established by plotting standard calibration curve over the concentration range of 5-30 ug/mL in both media $(\mathrm{N}=9)$. Least square regression analysis was done for the obtained data.

Limit of detection (LOD) and limit of quantitation (LOQ): LOD and LOQ were determined by using calibration curve data. Limit of detection was determined by using formula $3.3 \mathrm{\sigma} / \mathrm{S}$ and LOQ was determined by using formula $10 \mathrm{\sigma} / \mathrm{S}$ (where $\sigma$ is standard deviation of intercept and $S$ is the slope of calibration curve).

Robustness: Three different concentrations (LQC, MQC and HQC) are taken for assessment of robustness of proposed method by changing the $\mathrm{pH}$ of media by \pm 0.2 unit and calculating mean $\%$ recovery in both the media. 

PARAMETERS (EACH VALUE IS RESULT OF NINE SEPARATE DETERMINATIONS)

\begin{tabular}{|c|c|c|}
\hline Parameter & Phosphate Buffer (pH 6.8) & Hydrochloric acid buffer ( $\mathrm{pH} 1.2$ ) \\
\hline \multicolumn{3}{|l|}{ Optical characteristics } \\
\hline Apparent molar absorptivity $\left(1 \mathrm{~mol}^{-1} \mathrm{~cm}^{-1}\right)$ & $1.148 \times 10^{4}$ & $1.105 \times 10^{4}$ \\
\hline Sandell's sensitivity $\left(\mu \mathrm{gcm}^{-2} / 0.001 \mathrm{~A}\right)$ & 0.0246 & 0.0256 \\
\hline \multicolumn{3}{|l|}{ Regression analysis } \\
\hline Slope (S.E. $\left.{ }^{a}\right)$ & $0.0405\left(3.0 \times 10^{-4}\right)$ & $0.03904\left(2.87 \times 10^{-4}\right)$ \\
\hline $95 \%$ confidence limits of slope & $0.03765 ; 0.04335$ & $0.03732 ; 0.04073$ \\
\hline Intercept $\left(\right.$ S.E. $\left.{ }^{a}\right)$ & $0.0198\left(4.6 \times 10^{-3}\right)$ & $0.0598\left(6.2 \times 10^{-3}\right)$ \\
\hline $95 \%$ confidence limits of intercept & $-0.03568 ; 0.07517$ & $0.02666 ; 0.09303$ \\
\hline Standard error of estimate & $1.206 \times 10^{-3}$ & $1.468 \times 10^{-3}$ \\
\hline Regression coefficient $\left(r^{2}\right)$ & 0.998 & 0.999 \\
\hline \multicolumn{3}{|l|}{ Validation parameters } \\
\hline Linearity $\left(\mu \mathrm{g} \mathrm{mL} L^{-1}\right)$ & $5-30 \mu \mathrm{gLL}^{-1}$ & $5-30 \mu \mathrm{g} \mathrm{mL}^{-1}$ \\
\hline Limit of detection $\left(\mu \mathrm{g} \mathrm{mL}^{-1}\right)$ & $0.5294 \mu \mathrm{g} / \mathrm{mL}$ & $0.3186 \mu \mathrm{g} / \mathrm{mL}$ \\
\hline Limit of quantification $\left(\mu \mathrm{g} \mathrm{mL}^{-1}\right)$ & $1.6043 \mu \mathrm{g} / \mathrm{mL}$ & $0.9653 \mu \mathrm{g} / \mathrm{mL}$ \\
\hline Robustness (mean $\%$ recovery \pm S.D.) & $99.16 \pm 0.0014$ & $100.3 \pm 0.0067$ \\
\hline
\end{tabular}

Estimation from formulation: Five capsules were weighed and crushed the content. Amount of powder equivalent to 25 $\mathrm{mg}$ of milnacipran hydrochloride was weighed and extracted with phosphate buffer medium and hydrochloric acid medium separately for $0.5 \mathrm{~h}$ by sonicating the solution. The solutions were diluted suitably to prepare $20 \mathrm{ug} / \mathrm{mL}$ concentrations in respective media. Finally, solutions were filtered through whatman filter paper number 40 and filtrates were analyzed at $220 \mathrm{~nm}$ for both media respectively.

\section{RESULTS AND DISCUSSION}

The selection of the analytical media is crucial for estimation of milnacipran hydrochloride as milnacipran hydrochloride shows the $\mathrm{pH}$ dependent solubility. The $\mathrm{pH}$ of final media decided was $100 \mathrm{mM}$ phosphate buffer (pH 6.8) and $100 \mathrm{mM}$ hydrochloric acid buffer ( $\mathrm{pH}$ 1.2) based on sensitivity of method, cost and applicability of method to dissolution studies and ease of preparation. The $\lambda_{\max }$ of milnacipran hydrochloride was $220 \mathrm{~nm}$ in both phosphate buffer medium and hydrochloric acid buffer medium. Apparent molar absorbtivity of drug was found to be $1.105 \times 10^{4}$ and $1.148 \times 10^{4}$ in hydrochloric acid buffer medium and phosphate buffer medium respectively. Sandell's sensitivity of drug was found to be 0.0256 and 0.0246 in hydrochloric acid buffer medium and phosphate buffer medium respectively as shown in Table- 2 .

Calibration curve: The linear regression equation obtained at $220 \mathrm{~nm}$ was: absorbance $=\left[0.0405 \times\right.$ conc. in $\left.\mu \mathrm{g} \mathrm{mL}^{-1}\right]+$ 0.0198 with regression coefficient of 0.997 and absorbance at $220 \mathrm{~nm}=\left[0.0390 \times\right.$ conc. in $\left.\mu \mathrm{g} \mathrm{mL} \mathrm{m}^{-1}\right]+0.0598$ with regression coefficient of 0.999 in phosphate buffer and hydrochloric acid buffer medium respectively.

Specificity and selectivity: The UV spectrum of milnacipran hydrochloride was same as absorbance spectrum of pure drug alone and in presence of common excipients in both medium (Fig. 2). Hence, proposed methods are specific and selective for drug.

Accuracy: Accuracy in phosphate buffer was found to be in range of $-1.37 \%$ to $1 \%$ and $-0.63 \%$ to $0.89 \%$ in phosphate buffer medium and hydrochloric acid buffer medium respectively.
The mean \% recovery values are nearly $100 \%$ with low SD values $(<1.5)$ shows accuracy of method. The accuracy of proposed method was further validated by performance recovery studies of standard addition method (Tables 3 and 4). The mean recoveries (\% RSD) for lower, intermediate and higher conc. were found to be 100.04 (0.211), $99.86(0.225)$ and $100.04(0.167)$ respectively in phosphate buffer medium. Mean \% recovery (\% RSD) for lower, intermediate and higher conc. were found to be $100.10(0.324), 100.02(0.174)$ and $100.03(0.093)$ respectively in hydrochloric acid buffer medium. The result shows that the proposed method can accurately measure any small change in drug conc. in the solution.
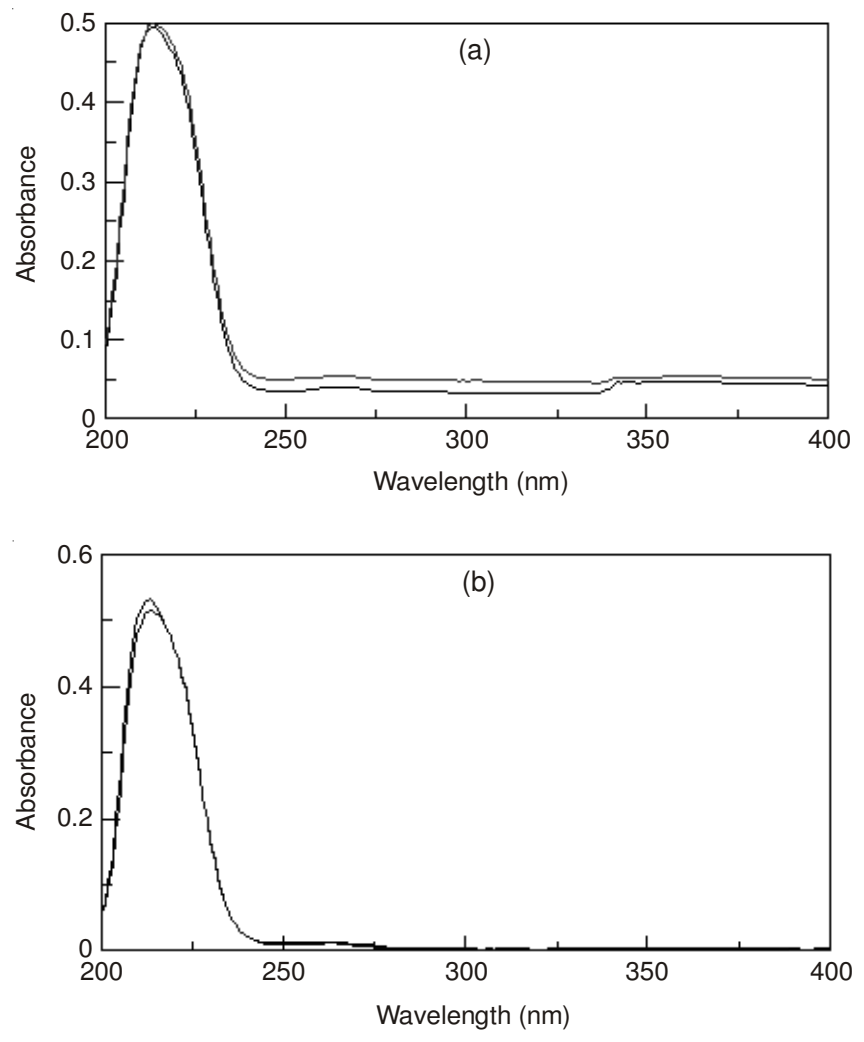

Fig. 2. (a) spectra in $\mathrm{pH} 6.8$ buffer, (b) spectra in $\mathrm{pH} 1.2$ buffer 


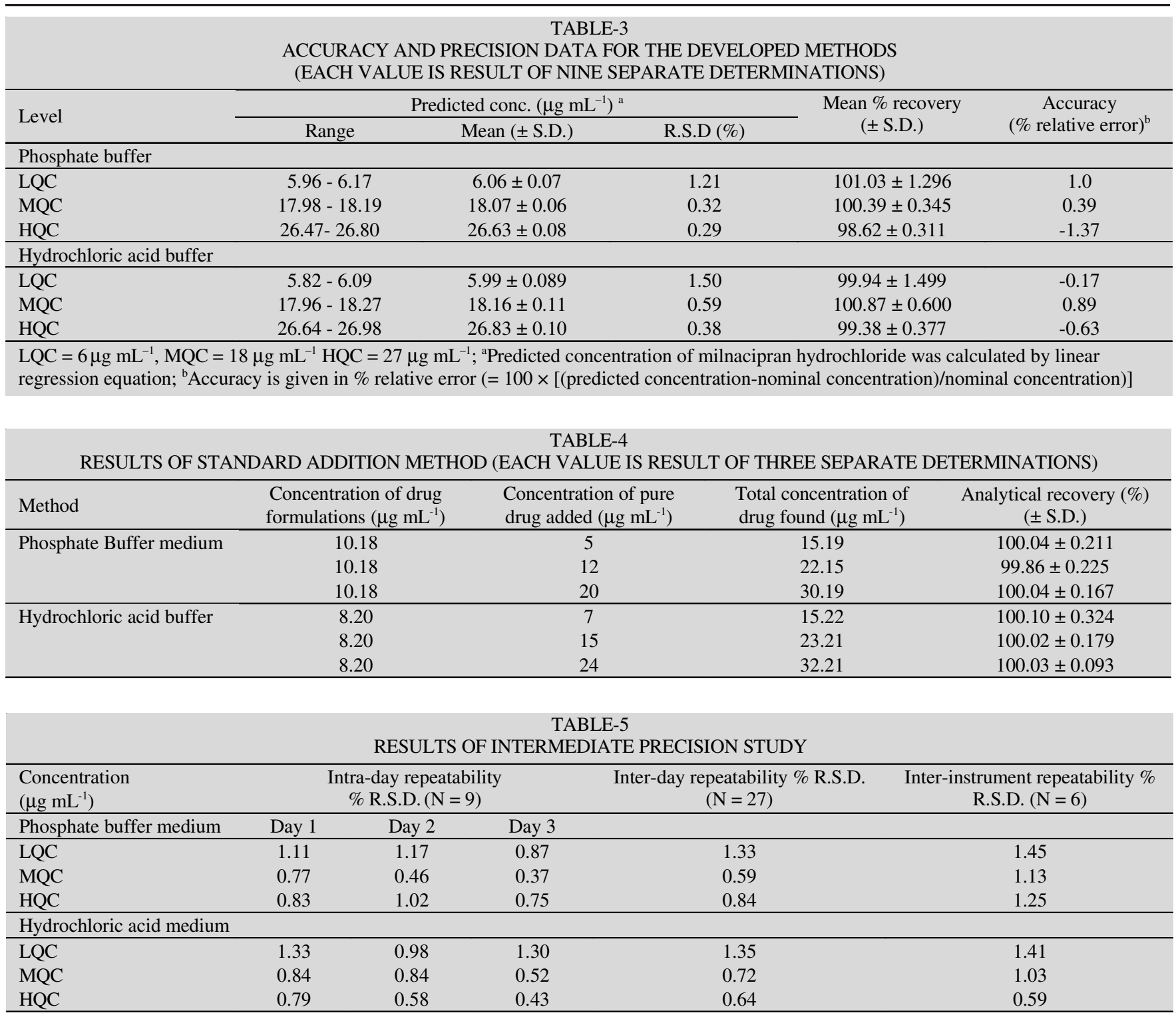

Precision: Precision of the proposed methods was studied by evaluating repeatability and intermediate precision. Repeatability (\% RSD) ranged from $0.37 \%$ to $1.17 \%$ and $0.43 \%$ to $1.33 \%$ in phosphate buffer medium and hydrochloric acid buffer medium respectively, at all three levels of concentrations (Table-5). This shows the precision under same operating conditions over a short interval of time in a day. Intermediate precision shows variations in different day. In intermediate precision study excellent \% RSD values were found out $(<1.5 \%)$ in all the cases.

This \% RSD values shows that these methods have good repeatability and intermediate precision.

Linearity: The linearity range was found to be $5-30 \mu \mathrm{g} /$ $\mathrm{mL}$ in both the selected media at $220 \mathrm{~nm}$. Lower values of parameters like standard error of slope and intercept (Table-2) indicated high precision of the proposed method. The mean slope and intercept values are within the $95 \%$ confidence interval.

LOD and LOQ: LOD and LOQ in phosphate buffer medium was found to be $0.5294 \mu \mathrm{g} / \mathrm{mL}$ and $1.6043 \mu \mathrm{g} / \mathrm{mL}$ respectively and in hydrochloric acid buffer medium LOD and
LOQ were found to be $0.3185 \mu \mathrm{g} / \mathrm{mL}$ and $0.9653 \mu \mathrm{g} / \mathrm{mL}$ respectively.

Robustness: Variation of $\mathrm{pH}$ of the selected media by \pm 0.2 did not have any significant effect on absorbance. The mean $\%$ recovery ( \pm S.D.) was found to be $100.94 \pm 0.54$ and 100.13 \pm 0.50 in the phosphate buffer and hydrochloric acid media, respectively (Table-6).

\begin{tabular}{ccc}
\multicolumn{3}{c}{ TABLE-6 } \\
RESULTS OF ROBUSTNESS STUDY \\
\hline \multirow{2}{*}{$\begin{array}{c}\text { Concentration } \\
\left(\mu \mathrm{g} \mathrm{mL}^{-1}\right)\end{array}$} & $\begin{array}{c}\text { Mhosphate buffer } \\
\text { medium } \mathrm{pH} 7\end{array}$ & $\begin{array}{c}\text { Hydrochloric acid } \\
\text { medium } \mathrm{pH} 1.4\end{array}$ \\
\cline { 2 - 3 } LQC & $100.20 \pm 1.48$ & $99.15 \pm 0.99$ \\
$\mathrm{MQC}$ & $100.94 \pm 0.54$ & $101.92 \pm 0.71$ \\
HQC & $98.34 \pm 0.31$ & $100.13 \pm 0.50$ \\
\hline${ }^{a}$ Each value is mean of three separate determinations
\end{tabular}

Estimation from formulation: In phosphate buffer the assay values of milnacipran hydrochloride for different formulations ranged from 99.41 to $100.39 \%$ with standard deviation not more than $1.17 \%$. In hydrochloric acid medium the assay 
TABLE-7

APPLICATION OF THE PROPOSED SPECTROPHOTOMETRIC METHODS TO THE DETERMINATION OF MILNACIPRAM HYDROCHLORIDE IN DOSAGE FORMS (EACH VALUE IS THE AVERAGE OF FIVE SEPARATE DETERMINATIONS)

\begin{tabular}{lcc|cc}
\hline \multirow{2}{*}{ Commercial products } & \multicolumn{2}{c|}{ Phosphate buffer medium } & \multicolumn{2}{c}{ Hydrochloric acid medium } \\
\cline { 2 - 5 } & Amount found & Assay $(\%)$ & Amount found & Assay $(\%)$ \\
\hline Milnace capsule $50 \mathrm{mg}$ (Torrent pharmaceutical Ltd. India) & $49.70 \pm 0.50$ & $99.41 \pm 1.0$ & $49.89 \pm 0.16$ & $99.77 \pm 0.32$ \\
Milborn capsule 50 mg (SUN Pharma. India) & $50.20 \pm 0.59$ & $100.39 \pm 1.17$ & $50.42 \pm 0.54$ & $100.85 \pm 1.07$ \\
\hline
\end{tabular}

values of milnacipran hydrochloride for different formulations ranged from 99.77 to $100.85 \%$ with standard deviation not more than $1.07 \%$ (Table-7).

\section{Conclusion}

The proposed methods are quite simple and do not require any pretreatment of the drug and tedious extraction procedure. The methods have wider linear range with good accuracy and precision. Hence, the data presented in the manuscript by spectrophotometric methods for the determination of milnacipran hydrochloride in its pure and dosage form demonstrate that the proposed methods are accurate, precise, linear, selective and offer advantages of reagent availability and stability, less time consumption and high sensitivity. Thus it can be extended for routine analysis of milnacipran hydrochloride in pharmaceutical industries, hospitals and research laboratories. Unlike the gas chromatography and high performance liquid chromatography procedures, the UV-visible spectrophotometer instrument is simple and not of high cost. Moreover the methods are free from interferences by common additives and excipients.

\section{ACKNOWLEDGEMENTS}

The authors are very thankful to Torrent Pharmaceuticals Limited (Ahmedabad, India) for providing with the gift sample of milnacipran.

\section{REFERENCES}

1. D.J. Kranzler and R.M. Gendreau, Neuropsychiatric Dis. Treat., 6, 197 (2010).

2. J. Tamiya, B. Dyck, M. Zhang, K. Phan, B.A. Fleck, A. Aparicio, F. Jovic, J.A. Tran, T. Vickers, J. Grey, A.C. Foster and C. Chen, Bioorg. Med. Chem., 18, 3328 (2008).

3. National Library of Medicine. Specialized Information Services: ChemIDplus Advanced. http://chem.sis.nlm.nih.gov/chemidplus/ chemidheavy.jsp (Accessed June 23, 2011).

4. K. Bartlett. Pharmacotherapy Update, 12(4), July/August (2009).

5. E. Lacassie, J.M. Gaulier, P. Marquet, J.-F. Rabatel and G. Lachatre, J. Chromatogr. B, 742, 229 (2000).

6. C. Duverneuil, G.L. Grandmaison, P. Mazancourt and J.C. Alvarez, Therap. Drug Monit., 25, 565 (2003).

7. C. Puozzo, C. Filaquier and G. Zorza, J. Chromatogr. B, 806, 221 (2004).

8. P. Dallet, L. Labat, M. Richard, M.H. Langlois and J.P. Dubost, J. Liq. Chromatogr. Rel. Technol., 25, 101 (2002).

9. P.J. Mehta and D.M. Khatri, Int. J. Pharm. Pharm. Sci., 2, 137 (2010).

10. M. Lecoeur-Lorin, R. Delépée, J.-P. Ribet and P. Morin, J. Sep. Sci., 31, 3009 (2008).

11. USP United States pharmacopoeia, NF 26. United States Pharmacopeia Convention, Asian edition, Rockville, edn. 31, pp. 683-687 (2008).

12. ICH, Q2R1 Validation of Analytical Procedures: Text and Methodology; International Conference on Harmonization, Geneva (1996).

13. ICH. Q1A(R2), Stability Testing of New Drug Substances and Products, International conference on Harmonization. Geneva (2003). 